\title{
THE EFFECT OF E-CONTENT BASED ON EACH DOMAIN OF MULTIPLE INTELLIGENCES ON LEARNINGIN BLENDED-LEARNING
}

\author{
Elaheh badiee $^{1}$, Mehran Farajollahi ${ }^{2}$, Seyed Ali Mohammad mousavi ${ }^{3}$ \\ ${ }^{1}$ Computer engineer, Master Student in Curriculum Development, South Tehran \\ Branch, Payamenoor University, Tehran, Iran - Member of Educational Computer \\ Group, Research Center of Teachers, Isfahan, Iran.(Corresponding Author) \\ ${ }^{2} \mathrm{PhD}$ in Curriculum, Associate Professor of Curriculum, South Tehran Branch, \\ Payamenoor University, Tehran, Iran \\ ${ }^{3} \mathrm{PhD}$ in Psychology, Assistant Professor of Psychology, Imam Khomeini International \\ University, Qazvin, Iran
}

\begin{abstract}
This study aimed to show the impact of learning strategies based on each multiple intelligences domain(analytical, introspective and interactive) on learning in blended learning.Thirty third-year computer science students in vocational high schools in Isfahan were randomly assigned to experimental and control groups (15 in each). The previous semester Average scores and multiple intelligences profiles were measured and were similar in both groups. Two groups were trained in 4 sessions (each 70 minutes) in the way of blended learning. In addition, the experimentalgroup used an electronic content based on multiple intelligences. The Pre-test and the post-test (before and after training) were the same in both groups. The Data were analyzed using SPSS-19 software by Chi-square test and independent samples ttest. The independent samples t-test on addend scores meaningfully shows more learning achievements for students who used E-Content based on multiple intelligences in introspective domain $(P=0.014)$.
\end{abstract}

\section{KEYWORDS}

Multiple intelligences, Blended Learning, E-Learning, E-Content

\section{INTRODUCTION}

Howard Gardner, a well-known psychologist, in 1983 categorizes the different ways of learning in a method called Multiple Intelligences include linguistic, logical-mathematical, musical, bodily-kinesthetic, spatial, interpersonal, and intrapersonal[1]aftera while he Added natural and Existential intelligencestothis collection[2].

He makes a map of human's abilities by grouping them into the eight comprehensive categories[3]. It is important, for any teacher, to release the Intelligence type of students and adopt teaching plan to student's individual learning styles.Gardnerdescribed these intelligencesas follows:

Linguistic: The Ability to understand and use spoken and written text effectively 
International Journal on Integrating Technology in Education (IJITE) Vol.2, No.3, September 2013

Logical-mathematical:Thecapacity tounderstand and use logic and numerical symbols and operations effectively

Musical:The Ability to perceive, understand, transform , and express musical forms

Spatial:The capacity to perceive and manipulate three-dimensional space accurately

Bodily-kinesthetic:The capacity to coordinate physical movement to express ideas and feelings and to produce or transform things using hands.

Naturalistic:The Ability to recognize and categorize objects or species in nature

Interpersonal:The Ability to understand and interact well with other people andinfluence a group of people to follow a certain line of action

Intrapersonal: Ability to understand and use one's thoughts, feelings, preferences, and interests and act adaptively on the basis of self-knowledge

Existential:TheAbility to thinking phenomena or questions related to universal existence, such as the infinite and infinitesimal. They need to see "the big picture" in order to learn details.[3][4][5].

To implementation the theory of multiple intelligences, we must translate the teaching material, from one intelligence to the languages of other intelligences [3].

In recent years, with the development of technology, terms like e-learning, distance learning, blended learning and virtual training are more common used. In addition, the concept of elearning as a learning method against or in combination with the traditional learning is proposed.

E-learning refers to all kinds of electronically supported learning and training include CBT (Computer-Based Training), WBT (Web-Based Training). CBTs are commonly presented via CD-ROM, while WBTs are presented via the Internet[6].

The traditional learning is combined with e- learning to create an optimum training program named blended learning [7].It provides a solution toadopting learning to the needs of individuals and integratesadvantages of e-learning and traditional learning. So, blended learning is a mix of face to face learning, in traditional classroom, with:

- Multimedia technology

- CD ROM video streaming

- Virtual classrooms

- Voicemail, email and conference calls

- Online text animation and video-streaming[8]

In fact, Blended Learning (BL) has the positive aspects of the online activities and face to face environment [9].

We know that everyone isdifferent and recognizingthese individualdifferences is necessary to have an effective learning.Blended learningprovidesa wide range oflearning solutions, so itisagreat opportunityto make a Diverse and individual-oriented learning as a fulllearning[10][8].

We can use advantages of the e-learning Environment to design learning curriculum based on these eight kinds of intelligence. David Lazear suggests a "Multiple intelligence technology toolbox" to design a Rich e-learning environment, as follow: 
International Journal on Integrating Technology in Education (IJITE) Vol.2, No.3, September 2013

Table 1.The Lazear "Multiple intelligence technology toolbox" (taken from yi donga,[10] )

\begin{tabular}{|c|c|}
\hline $\begin{array}{l}\text { Intelligences } \\
\text { types }\end{array}$ & The design strategy of e-Learning environment \\
\hline \multirow[t]{10}{*}{ Linguistic } & 1. Providing text resources \\
\hline & 2. Using of video on demand technology, provide video and audio \\
\hline & 3. Providing the opportunity to dictation \\
\hline & $\begin{array}{l}\text { 4. Through via voice chat rooms, or OICQ debating and communicating on } \\
\text { the exchange of voice }\end{array}$ \\
\hline & $\begin{array}{l}\text { 5. Through electronic forums, E-Mail, chat rooms, virtual classrooms, OICQ, } \\
\text { etc. to discuss and exchange Comments }\end{array}$ \\
\hline & 6. Students tell stories to the students or lecture \\
\hline & 7. Using network to Collect resources \\
\hline & 8. Providing read aloud opportunities \\
\hline & 9. Using Microsoft Word software for writing, keep a diary \\
\hline & 10. Providing With CD-ROM, interactive books, e-books \\
\hline \multirow[t]{10}{*}{ Logical } & $\begin{array}{l}\text { 1.Using concrete steps, computing processes, methods, formulas and equations } \\
\text { to solve problems }\end{array}$ \\
\hline & $\begin{array}{l}\text { 2.Use sign language to understand and exchange, sorting the logical order of } \\
\text { things }\end{array}$ \\
\hline & 3. Using the database to overview and organization a variety of information \\
\hline & $\begin{array}{l}\text { 4. Use spreadsheet programs (such as Excel)to process and analysis data for } \\
\text { some subject }\end{array}$ \\
\hline & 5. Using the data model represents the relationship between things \\
\hline & 6. Searching and analyzing for the required network resources \\
\hline & 7. Using the programming language programming \\
\hline & 8. Setting out appropriate procedures to solve the problem \\
\hline & 9. On an issue in logical deductive reasoning \\
\hline & 10. Participating in the network math games \\
\hline \multirow[t]{10}{*}{ Spatial } & 1. Using charts, diagrams or photographs to support the textual representation \\
\hline & $\begin{array}{l}\text { 2. Using visual outline, concept mapping, mind mapping, clustering, or } \\
\text { thinking depicted [3] records of learning content }\end{array}$ \\
\hline & 3. Express the meaning implied in graphics or images \\
\hline & $\begin{array}{l}\text { 4. Creating abstract graphics and patterns to reflect the relationship of the } \\
\text { different concepts, ideas or methods }\end{array}$ \\
\hline & 5. Designing charts, concepts, ideas and methods of learning \\
\hline & $\begin{array}{l}\text { 6. Using PhotoShop to create and edit photos, using web processing to } \\
\text { produce web pages }\end{array}$ \\
\hline & 7. Using animation and video media to characterize learning content \\
\hline & 8. Making full use of color to emphasize on learning content \\
\hline & $\begin{array}{l}\text { 9. Changing the shape or the size of the graphic, and improving their memory } \\
\text { from the visual attention }\end{array}$ \\
\hline & $\begin{array}{l}\text { 10. Using animation software, video editing software, and computer-aided } \\
\text { design software to create }\end{array}$ \\
\hline \multirow[t]{2}{*}{ Musical } & 1. Show learning materials, provide background music \\
\hline & $\begin{array}{l}\text { 2. Through the music to create a pleasant atmosphere, relax, inspire, focus } \\
\text { and achieve the transition }\end{array}$ \\
\hline
\end{tabular}


International Journal on Integrating Technology in Education (IJITE) Vol.2, No.3, September 2013

\begin{tabular}{|c|c|}
\hline & 3. Play music, ask students to concept $f$ the screen through the music \\
\hline & 4. Play music so that students take the initiative to construct listening \\
\hline & 5. Spell the word through music \\
\hline & 6. Learn to read through music \\
\hline & 7. use computer software to do music composition \\
\hline & $\begin{array}{l}\text { 8. use music and sound production and editing software (such as Sound } \\
\text { Maker) to edit sound }\end{array}$ \\
\hline & 9. Sing the song in Concert with the title of studying \\
\hline & 10. Provide through poetry, song lyrics to carry out learning opportunities \\
\hline \multirow[t]{4}{*}{$\begin{array}{l}\text { Bodily- } \\
\text { kinesthetic }\end{array}$} & $\begin{array}{l}\text { 1. creating virtual reality environment, giving students the opportunity to } \\
\text { simulate the operation }\end{array}$ \\
\hline & $\begin{array}{l}\text { 2. Provide a virtual laboratory for students to conduct virtual experiments by } \\
\text { computer }\end{array}$ \\
\hline & $\begin{array}{l}\text { 3. The establishment of a variety of interactive navigation methods to enable } \\
\text { students to learn through the operation }\end{array}$ \\
\hline & $\begin{array}{l}\text { 4. According to learning content design needs keyboard, mouse, joystick or } \\
\text { other device of the game }\end{array}$ \\
\hline \multirow[t]{10}{*}{ Interpersonal } & 1. Through the network to carry out distance learning courses \\
\hline & 2. through OICQ ,chat rooms or E-mail to communicate \\
\hline & 3. Holding an online forum \\
\hline & 4. The use of video conferencing systems to communicate and discuss \\
\hline & 5. Simulating games, using software or games need to work together \\
\hline & 6. Organizing cooperative learning with others in the group to study a topic \\
\hline & $\begin{array}{l}\text { 7. Playing different roles in the virtual community to, express their } \\
\text { understanding, empathy training from themselves points of view or life } \\
\text { experiences. }\end{array}$ \\
\hline & 8. accepting others opinions or responding to others performance or views \\
\hline & 9. predict the emotion or experience of people in a particular scenario \\
\hline & $\begin{array}{l}\text { 10. Concerned about the relationship between people and how to improve this } \\
\text { relationship }\end{array}$ \\
\hline \multirow[t]{10}{*}{ intrapersonal } & 1. Students choose learning contents and self-paced \\
\hline & 2. enable students to learn independently \\
\hline & 3. help students set goals and provide feedback \\
\hline & 4. Using a variety of scales for detect themselves \\
\hline & $\begin{array}{l}\text { 5. The use of blog which enable students to learn to write diaries, records, or } \\
\text { reflective thinking diary }\end{array}$ \\
\hline & $\begin{array}{l}\text { 6. Provide only one person to do or to encourage independent learning } \\
\text { computer games or programs }\end{array}$ \\
\hline & 7. enable students to describe their own thought processes \\
\hline & $\begin{array}{l}\text { 8. provide an opportunity to students with a particular subject to express } \\
\text { personal feelings and ideas }\end{array}$ \\
\hline & 9. ask students to use different ways of thinking to solve different problems \\
\hline & $\begin{array}{l}\text { 10. provide material about the personal reality life for students to consider } \\
\text { and choose }\end{array}$ \\
\hline Naturalistic & $\begin{array}{l}\text { 1. Provide the image of a real response to the natural environment for } \\
\text { students }\end{array}$ \\
\hline
\end{tabular}


International Journal on Integrating Technology in Education (IJITE) Vol.2, No.3, September 2013

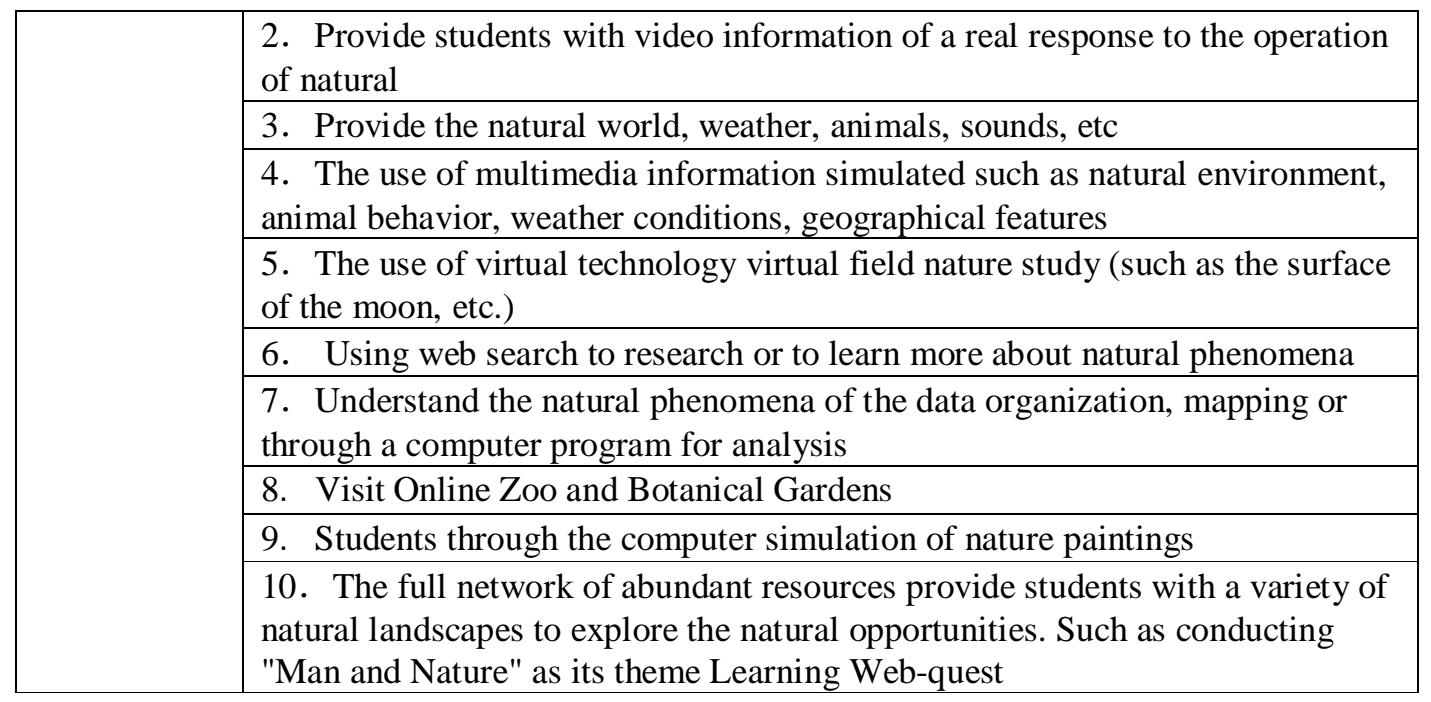

Walter McKenzie suggested 3 intelligences domains as Figure (1). Heorganizedlogical, musical and naturalisticintelligences as analytic domain becausethey are exploratory processes and they essentially develop the process of analyzing and incorporating data into existing schema.

The interactive domain includes verbal, interpersonal, and kinesthetic intelligences that generally used by learners to express themselves and discover their environment.

The introspective domain includes existential, intrapersonal and spatialintelligences that have a distinctly affective component to them.Mackenzie emphasized on a balance between these three domains in instructional design [11].

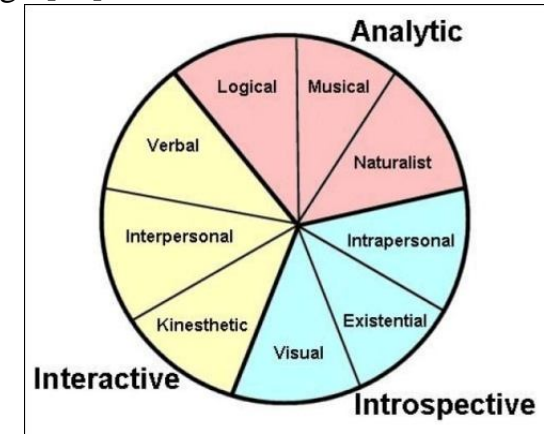

Figure 1.multiple intelligences domains( taken from:McKenzie, [11])

\subsection{LITERATURE REVIEW}

There are so many studiesonthe effectiveness ofteaching methodsbased onGardner's multiple intelligences:

Based on researchofAvila[12] and Pahuski (1999)[12], instructionalstrategiesbased onGardner's theory to learnacademiclanguageskills meaningfully increased the learning achievement of studentwhohave difficultyinLearninglanguageskills.Xie, Lin (2009)[13] and Abdi\&et al(2011) [14]alsoin their researchessaid that using the theory ofmultiple intelligences inteaching,leadstohigheracademic achievement.Niroo, et al (2011) [15]believed that educational methodsbased on thetheory ofmultiple intelligences, meaningfully increased mathacademic 
International Journal on Integrating Technology in Education (IJITE) Vol.2, No.3, September 2013

achievementof students with low logicalintelligence, but there wasno significant differenceinother students. The results of Rahimi's[16]research (2011)showed a higher reading ability for students with a higher level of linguistic intelligence than those who had a lower level of this intelligence.Moreover, the results indicated that linguistic intelligence is a relatively strong predictor of reading performance, accounting for more than $40 \%$ of the variance observed in the students' performance on the reading comprehension test. The results of Razmjoo's[17]research(2008)on the Iranian learners, revealed no significant relationshipbetween multiple intelligences and English language proficiency. According to Johnson'sliterature (2007)[18], implementation multiple intelligences theory in teaching,significantly increased students' achievement in all areas of the core curriculum.In field of e-learning,Hassan(2009) [19]performed a research to exploring the reaction of learners to CBL material based on different learning styles and Compared between pre and post test scores and these scores were broken down by learning styles and experimental and control groups and found no significant relationship between academic achievements and either learning styles or experimental and control groups.

But, only a few researches were performed on multiple intelligences learning strategies in electronic or blended learning and their effects.

\subsection{RESEARCH QUESTIONS}

In this study, we have following three research questions:

Would the use of e-content designed based onthe analytical intelligences domain, increase the learning achievement of the students, in blended learning?

Would the use of e-content designed based on the introspective intelligences domain, increase the learning achievement of the students, in blended learning?

Would the use of e-content designed based onthe interactiveintelligences domain, increase the learning achievement of the students, in blended learning?

\section{METHODS:}

This study aimed to show the impact of learning strategies based on each multiple intelligences domain (analytical, introspective and interactive) on learning in blended learning. The participants for this study were female third graders computer science students $(\mathrm{N}=30)$ at a public vocational high school in isfahan. They were randomly divided in two groups, an experimental group $(\mathrm{N}=15)$ and a control group $(\mathrm{N}=15)$.

Multiple intelligences profiles were measured in two groups by Mackenzie questionnaire[20] with 80 items, before investigation.Also, the previous semester Average scores of all students measured.A researcher made multiple choices test was designed in 3 parts(each part related to teaching content based on one of domains) as the pre-test and the post-test. The pre-test was performed in both groups and then Both groups were trained in blended learning environment by the same teacher, in the same lesson, using the same textbook, in the same time for 4 session(each 70 minutes). In addition, the experimentalgroup used an electronic content based on multiple intelligences theory. This e-content made in three parts (each part designed based on one of multiple intelligences domains) and was shared via network in classroom. Formaking this e-content, researcher used Lazear "Multiple intelligence technology toolbox" (table2), regardless of the implementation of the Existential intelligence, because of the lack of sufficient 
International Journal on Integrating Technology in Education (IJITE) Vol.2, No.3, September 2013

information about it. A week after the learning process, the same test was performed in both groups (as a post- test) and then, the addend scores in academic achievement for students who taught with each method, was calculated. Data analyses were performed using SPSS-19 software. The researcher used a chi-square test to check consistency of two groups in terms of age, multiple intelligences profiles; and used a t-test analysis for non-independent samples to comparing the addend scores.

\section{RESUlts}

In this study, the mean and the Standard deviation ofage inthe experimental group was 17.2 \pm 0.56 and in the control group was17.13 \pm 0.35 . There was no significant difference between the groups in terms of age $(\mathrm{t}=-0.699, \mathrm{p}=0.035)$. The mean of previous semester Average scoresand the standard deviation of the experimental group was15.61 \pm 1.5 and in the control group was $15.76 \pm 1.6$. There was no significant difference between the groups in terms the mean of previous semester Average scores $(\mathrm{t}=-0.254, \mathrm{p}=0.802)$ and all participants were female.

The resultsinTable (1)show thatin bothgroups, the most frequent intelligences are interpersonalintelligenceand then spatial intelligence.

Table 2. The number andfrequency ofpeoplewith anyintelligence, in twogroups

\begin{tabular}{|l|l|l|}
\hline Intelligence type & $\begin{array}{l}\text { the experimental group } \\
\text { count (Percent) }\end{array}$ & $\begin{array}{l}\text { the control group } \\
\text { count(Percent) }\end{array}$ \\
\hline Intrapersonal & $9(60 \%)$ & $7(46.7)$ \\
\hline Bodily- Kinesthetic & $1(6.7)$ & $0(0 \%)$ \\
\hline Spatial & $4(26.7)$ & $4(26.7)$ \\
\hline Logical & $0(0 \%)$ & $1(6.7)$ \\
\hline Musical & $1(6.7)$ & $2(13.3)$ \\
\hline Multiple & $0(0 \%)$ & $1(6.7)$ \\
\hline
\end{tabular}

According to table (3), theintelligencesofthe two groupswere significantly not different $(\mathrm{p}<0.05)$.

Table 3. The Comparison oftwogroups in term of multipleintelligence, using qi-square test

\begin{tabular}{|l|l|l|}
\hline value & df & p \\
\hline 3.583 & 5 & 0.611 \\
\hline
\end{tabular}

The comparison of mean scores in two groups reveals that before the experiment, control group's scores were higher than experimental group, while after the experiment, control group's scores were less than experimental group. The comparison of addend scores shows that the addend scores of the experimental group, who used e-content based on introspective intelligences domain, significantly $(\mathrm{p}<0.05)$ higher than the addend scores of the control group (table 4).

This comparison in analytical domain shows that in this method, that pre-test and post test scores of control group were higher than experimental group. The comparison of addend scores shows that they were significantly not different $(\mathrm{p}<0.05)$ and this method had noeffect on learning achievements (table 4). 
International Journal on Integrating Technology in Education (IJITE) Vol.2, No.3, September 2013

This comparison in interactive domain reveals that in this method, the pre-test and the post test scores of the experimental group were higher than the control group. The comparison of addend scores shows that they were significantly not different $(\mathrm{p}<0.05)$ and this method had noeffect on learning achievements (table 4).

Table 4. The comparison of mean of addend scores in two groups

\begin{tabular}{|l|l|l|l|l|l|l|}
\hline $\begin{array}{l}\text { Intelligences } \\
\text { Domain }\end{array}$ & Group & $\begin{array}{l}\text { Pre-Test } \\
\text { Scores }\end{array}$ & $\begin{array}{l}\text { Post-Test } \\
\text { Scores }\end{array}$ & $\begin{array}{l}\text { Addend } \\
\text { Scores }\end{array}$ & $\mathbf{t}$ & P \\
\hline \multirow{2}{*}{ analytical } & Experimental & $4.93 \pm 1.44$ & $5.6 \pm 1.40$ & $0.67 \pm 1.54$ & -0.101 & 0.921 \\
\cline { 2 - 6 } & Control & $4.6 \pm 1.50$ & $5.33 \pm 1.80$ & $0.73 \pm 2.05$ & & \\
\hline introspective & Experimental & $4.2 \pm 1.52$ & $7.13 \pm 1.30$ & $3.07 \pm 1.58$ & 2.614 & 0.014 \\
\cline { 2 - 5 } & Control & $4.6 \pm 1.68$ & $5.80 \pm 2.21$ & $1.47 \pm 1.77$ & & \\
\hline \multirow{2}{*}{ interactive } & Experimental & $3.47 \pm 2.36$ & $5.07 \pm 1.94$ & $1.6 \pm 2.38$ & .0169 & 0.867 \\
\cline { 2 - 5 } & Control & $4.67 \pm 1.92$ & $6.13 \pm 1.96$ & $1.47 \pm 1.92$ & & \\
\hline
\end{tabular}

\section{CONClusion}

This study aimed to show the impact of learning strategies based on each multiple intelligences domain (analytical, introspective and interactive) on learning in blended learning. According to the results, the study groups were not significantly different in terms of gender, age, last previous semester Average scores and multiple intelligences profiles.The results of this study reveal that learning strategies based on introspective intelligences domain, has been effective to increase learning, in blended learning.

These findings in introspective intelligences domain are consistent with the results of researches conducted by Avila(1999), Niroo(2011), Xie(2009), Johnson(2007) and Abdi(2011) those researches were performed in face to face learning method, while this study conducted in blending learning method. This study shows that the results be generalized, and e-content designed based on Gardner's theory can improve the learning achievements in blended learning.The success of introspective domain can be due to dominance of intelligences within this domain (intrapersonal and spatial) in participants in this study and diversity of the visual tools in e-learning environment.

According to the results of this study, the blended Learning strategies based on analytical and interactive domain were not effective to increasing learning achievements. These findings are inconsistent with the findings of previous studies that mentioned above. Weaknesses of elearning tools in creating desirable interact can be a good reason for failure of e-content designed based on interactive domain in blended learning.

Similar studies on other groups of learners with different characteristics are suggested.It is recommended to use the Learning strategies based on the theory of multiple intelligences, especially intrapersonal and spatial intelligences, to designing the e-content.

\section{REFERENCES}

[1]. Anna,Munger.\& Amanda, Sanders.\& Teri, Smith.(2011)Multiple Intelligences: Can MI be an Effective Tool in the Classroom?,Brigham Young University-Idaho.

[2]. Gardner, H. (1999). Intelligence Reframed. Multiple Intelligences for the21st Century. New York: Basic Books.

[3]. Armstrong,Thomas(2009)Multiple Intelligences in Classroom,ASCD. 
International Journal on Integrating Technology in Education (IJITE) Vol.2, No.3, September 2013

[4]. Moran, S.\&Kornhaber, M.\& Gardner, H.(2006). "Orchestrating multiple intelligences",Teaching to Student Strengths, Vol. 64, No. 1,pp 22-27.

[5]. Palmberg, Rolf.(2011) Multiple Intelligences Revisited, Palmsoft Publication.

[6]. Wikipedia, the free encyclopedia. (2013). E-learning, http://en.wikipedia.org/wiki/E-learning, accessed 18/2/2013.

[7]. Bersin, josh. (2004) The Blended Learning Book: Best Practices, Proven Methodologies and Lessons Learned, San Francisco: Pfeiffer.

[8]. Thorne,kaye.(2003) Blended Learning: How integrate Online and Traditional Learning, London:kogan page.

[9]. Demirli, Cihad.\&Aksogan, Mustafa.(2012) "The Effect of Blended Learning on the Persistence of Academic Performance for Computer Education",The Journal of Instructional Technologies \&Teacher Education, Vol.1, No1, pp111-122.

[10]. Yi-donga, FENG.\& Zhan-jib, GUI.\& Yun-duanc, FANG.\& Xiao-xiaa, WANG. ( 2011)"The Research Of E-Learning Environment Design Based On The Theory Of Multiple Intelligences",Education And Management Engineering, no 5,(available at: http://www.mecspress.net),49-54.

[11]. Mckenzie, Walter. L.(2004)surfaquarium consulting, (available on: http://surfaquarium.com).

[12]. Avila, Judy.\&Pahuski, Linda.(1999)Developing Language Arts Skills Through Reading and Writing Connection, Master's Action Research Project, Saint Xavier University.

[13]. Xie, Jingchen.\& Lin, Ruilin. (2009) "Research on Multiple Intelligences Teaching and Assessment", Asian Journal of Management and Humanity Sciences, Vol. 4, No. 2-3,106-124.

[14]. Abdi, Ali.\&Nouroozi,Daryoosh.\&Maleki, Hassan.\&Ebrahimi,Ghavam.Soghra.(2011) "Comparing The Effectiveness ofTeachingStrategiesBased onMultiple IntelligenceandCommon Teaching Method onLearningAchievementandAttitudes ofStudents InFifth Grade Student in Science Class", Journal of Educational Innovations, no. 101,pp37-120.

[15]. Niroo, Mohammad.\&Hajihoseini.Nejad,Gholamreza.\&Haghani, Mohammad.(2011)"The Effect of Gardner'sTheory ofMultiple IntelligencesBasedInstructiononMathematicsAchievementof FirstGrade High SchoolStudents", Journalof Educational Leadership\&Administration, vol. 5, no. 2, pp.153-168.

[16]. Rahimi,M.\&Sadighi,F.\&Hosseiny.Fard,Z. (2011) "The Impact Of Linguistic And Emotional Intelligence On The Reading Performance Of Iranian Efl Learners", The Journal of Teaching Language Skills (JTLS), vol. 3, no. 1, pp.151-171.

[17]. Razmjoo,Seyyed. Ayatollah.(2008) "On The Relationship Between Multiple Intelligences And Language Proficiency", The Reading Matrix, Vol. 8, No. 2, pp155-174.

[18]. Johnson, Marisa.(2007)The Effect of Multiple Intelligences on Elementary Student Performance, for the Degree Master of Science in Education , School of Education Dominican University of California, San Rafael(CA).

[19]. Hassan,Razali.(2009)How do Students Respond to CBL material based on VARK Learning Style, Teaching \& Learning Open Forum.

[20]. McKenzie, (1999) W. MultipleIntelligences Survey, (availableat:http://surfaquarium.com/MI/inventory.htm).

\section{Authors}

Elahehbadiee, (Corresponding Author), received her bachelor degree in Computer engineering from Najafabad branch of azad university, iran in 1987 and is Master Student in Curriculum Development in South Tehran Branch, Payamenoor University, Tehran, Iran. She is a teacher and teaches computer science since 1988. She is Member of Educational Computer Group of Research Center of Teachers, Isfahan, Iran. She interests to researches in fields of education and training especially in computer sciences.

MehranFarajollahi, is Associate Professor of Curriculum and teaches in South Tehran Branch of Payamenoor University, Tehran, Iran. He interests to researches in fields of education and training.

Seyed Ali Mohammad mousavi, isAssistant Professor of Psychology andteaches in Imam Khomeini International University, Qazvin, Iran. He interests to researches in fields of Psychology and educational Psychology. 